\title{
An Assessment on Laboratory Safety Knowledge among Allied Health Sciences Students at the University of Sri Jayewardenepura
}

\author{
Withanage ND and Priyadarshani AMB \\ Department of Allied Health Sciences, Faculty of Medical Sciences, University of Sri Jayewardenepura, Sri \\ Lanka
}

\begin{abstract}
This study was carried out to determine the knowledge regarding laboratory safety precautions amongst Allied Health Sciences students at the University of Sri Jayewardenepura. A cross-sectional study on laboratory safety knowledge of Allied Health Sciences students was conducted using a standardized, 60-item structured self-administered questionnaire. The questionnaires were administered to 229 of students. The statistical data was generated using SPSS 16th version. The students who obtained scores of $\geq 75,74-60,50$ 59 and $\leq 49$ were categorized as "excellent", "good", "moderate" and "poor" knowledge, respectively regard to laboratory safety precautions. Participants included the students from B. Pharmacy $36.7 \%(n=84)$, B.Sc. in Medical Laboratory Sciences (MLS) 45.4\% (n=104) and B.Sc. (Nursing) $17.9 \%(n=41)$, degree programs. Students' overall knowledge towards the laboratory safety precautions as follow; excellent $7.4 \%$ $(n=17)$, good $27.5 \%(n=63)$, moderate $22.7 \%(n=52)$ and poor $42.4 \%(n=97)$. Students had a "good" knowledge in relation to safety laboratory practices, personal protective equipment, traceability and waste disposal. Knowledge regarding gas, chemical storage and glassware hazards was "moderate". But knowledge was "poor" regard to safety equipment, emergency procedures, health awareness, laboratory equipment and instruments. A significant difference $(p<0.05)$ related to knowledge on laboratory safety precautions was observed among three degree programs: B. Pharmacy: excellent $1.2 \%(n=1)$, good 10.7\% $(n=9)$, moderate $23.8 \%(n=20)$, poor $64.3(n=54)$, B.Sc. in MLS: excellent $15.4 \%(n=16)$, good $49 \%(n=51)$, moderate $18.3 \%(n=19)$, poor $17.3 \%(n=18)$ and B.Sc. (Nursing); good $7.3 \%(n=3)$, moderate $31.7 \%$ $(n=13)$, poor $97 \%(n=61)$. But there was no significant difference was observed among the students belong to different academic years within the same degree program. It is concluded that the knowledge on laboratory safety precautions amongst Allied Health Sciences students is inadequate.
\end{abstract}

KEYWORDS: Laboratory safety precautions, laboratory hazards, safety awareness

Corresponding author: A. M. B. Priyadarshani, Email: priyadarshani@sjp.ac.lk 


\section{INTRODUCTION}

B.Sc. in Medical Laboratory Sciences (MLS), B. Pharmacy and B.Sc. (Nursing) govern under the Department of Allied Health Sciences at University of Sri Jayewardenepura, Sri Lanka are greatly dealing with laboratory based learning methods. Out of all three degree programs B.Sc. in MLS is essentially a medical laboratory based degree program. The students accomplish an enormous number of practical sessions including Microbiology, Haematology, Histopathology, Chemical Pathology and Parasitology during their course of study (Prospectus, Allied Health Sciences Degrees, Faculty of Medical Sciences, University of Sri Jayewardenepura, 2012). In addition to the university setting, students gain comprehensive laboratory exposures from the medical laboratories in hospitals (Prospectus, Allied Health Sciences Degrees, Faculty of Medical Sciences, University of Sri Jayewardenepura, 2012). Therefore these undergraduates perform routine laboratory procedures on numerous clinical specimens including blood, urine, faeces, sputum, tissue and other body fluids from the patients suffering from variety of infections. Hence there is a possibility to expose them to infections such as hepatitis B virus (HBV), hepatitis $\mathrm{C}$ virus (HCV) and human immunodeficiency virus (HIV) and other blood borne infections if satisfactory safety measures are not taken (Nwabuisi \& Olatunji, 1999; Falope et al., 1998).

The students of B.Sc. (Nursing) Degree programs are also extensively dealing with a number of practical based trainings in the university. In addition to that, these students gain clinical experience in a variety of settings especially from the hospitals over the whole course of four years (Prospectus, Allied Health Sciences Degrees, Faculty of Medical Sciences, University of Sri Jayewardenepura, 2012). However, knowledge regarding universal precautions is extremely important for the students of B.Sc. (Nursing) degree program as their career is greatly dealing with clinical aspects. In addition to the practical based learning, the students from B. Pharmacy degree program are offered one year of internship at hospitals, Medical Research Institute, National Drugs Quality Assurance Laboratory etc. (Prospectus, Allied Health Sciences Degrees, Faculty of Medical Sciences, University of Sri Jayewardenepura, 2012). It becomes clear from the above mentioned facts that knowledge regarding universal precautions is extremely important for the students of Allied Health Sciences Degree program.

The laboratory setting can be a hazardous place to work since it mainly endow with microbial, chemical, glassware, equipment, radiation and explosion hazards. Therefore the workers are usually faced with various hazards at work. As a result the person's health and safety may be severely threatened unless satisfactory preventive defensive measures are not taken (Zaveri \& Karia, 2012).

It is documented that among health-care workers, annual proportions exposed to bloodborne pathogens are as follows; $2.6 \%$ for $\mathrm{HCV}$, $5.9 \%$ for $\mathrm{HBV}$ and $0.5 \%$ for HIV, corresponding to about $16,000 \mathrm{HCV}$ infections and 66,000 HBV infections in health-care workers worldwide. However, they seem to have lack of perception of the danger of infections and are not compliant with the basic principles of safety precautions (Adebamowo \& Ajuwon, 1997; Brusaferro, 1997). Amongst health-care workers the majority is injured by needles, scalpels and other sharp instruments and devices which are contaminated with blood and other body fluids. This system of infection control is therefore very important to minimize the risk of transmission of infections in the laboratory, as workers may not be aware of the outcome of blood and fluid specimens until they are investigated (Zaveri \& Karia, 2012). Another study has revealed that accidents occurring in the Pathology laboratories of Hospital Ipoh as Histology (40\%), Microbiology (33\%), Haematology (20\%) and Cytology (7\%) laboratories. Forty seven 
percent of the incidents were due to cuts by sharp objects. About $27 \%$ of the injuries are due to splashes and squirts by blood or chemicals. There was one case from following; contact with bio-hazardous fluid, burn, hypersensitivity reactions and drinking of disinfectant accidentally (Karim \& Choe, 2000). Furthermore awareness regarding hazards of the chemicals, radiation, fire and waste disposal are vital. Statistical data has been shown that in the UK, explosions and fires related to works account for more than 5000 burn injuries per year (Mian, 2011). However above findings are emphasized that attitudes, perception and practice of laboratory workers about safety precautions are tremendously important. The avoidance of hazards in laboratories requires a thorough understanding regarding the risks and the laboratory personnel should be familiarized themselves with "universal precautions" (Zaveri \& Karia, 2012). Especially, laboratory at university is the place where undergraduate students first develop their laboratory practices and the practice they learnt from the laboratory may carry throughout their careers. Therefore the present study was undertaken to evaluate the knowledge of students from the Department of Allied Health Sciences at the University of Sri Jayewardenepura regarding laboratory safety measures.

\section{MATERIALS \& METHODS}

\subsection{Study Design}

This was a cross-sectional study which used a standardized, structured self-administered questionnaire to survey knowledge regarding laboratory safety precautions among Allied Health Sciences students at University of Sri Jayewardenepura, Sri Lanka. The identity of participants was protected as participants' names were not required. Data were recorded anonymously, and confidentiality was maintained; only the degree program and the academic year were known. Completed questionnaires were retrieved immediately by the study investigators. Prior to commence the study, the Ethical clearance was obtained from the Ethical Review Committee, Faculty of Medical Sciences, University of Sri Jayewardenepura, Sri Lanka.

\subsection{Survey Instrument}

The questionnaire was self-generated and developed by adapting guidelines on universal work precautions. It was self-administered and consisted of sixty standardized questions which covered eleven different aspects related to laboratory safety precautions as follow; (i) Personal protective equipment; eg., wearing of gloves, lab coats, aprons, covered-shoes, eye \& respiratory protection equipment (ii) Location $\&$ operation of safety equipment; eg., fire extinguisher, eye washers \& safety showers (iii) Safety laboratory practices; eg., decontamination of laboratory bench tops before leaving the laboratory, hazard warning labels (iv) Emergency procedures eg., maintaining an accident register, telephone numbers of authorized persons to whom an emergency should be informed, awareness on spill control kits (v) Health awareness eg., annual tuberculosis (TB) screening, vaccination against Hepatitis B, awareness regarding permissible exposure limit of hazardous chemicals (vi) Laboratory equipment \& instruments eg., awareness whether scientific instruments are in working order and in good condition, correct handling of the scientific instruments (vii) Glassware hazards eg., use of high temperature or heat resistant - "Pyrex" glassware depending on the requirement, wearing protective gloves while cleaning glassware (viii) Gas eg., closing of valves of gas cylinders when not in use (ix) Chemicals \& clinical specimens storage eg., allocation of refrigerators and freezers according to contamination levels (x) Traceability eg., labeling of reactive agents and samples with name, date, storage temperature, expiry date (xi) Waste disposal eg., handling of all types of (biological, chemical, radioactive etc.) waste 
containers properly, segregation \& collection of wastes in suitable containers.

\subsection{Study Population}

The questionnaires were administered to a batch of 229 students who belong to B.Sc. in MLS, B. Pharmacy and B.Sc. (Nursing) degree programs. In B.Sc. in MLS and B. Pharmacy programs, students of first-fourth year participated whereas in B.Sc. (Nursing) program only the students of second-fourth year participated. The students from first year of B.Sc. (Nursing) program had no laboratory exposure in the university at the time when the study was commenced. Hence they volunteered to decline from the study. Before questionnaires were handed out to participants, the aims and objectives of the study were explained to them. The students were given their verbal consent to participate in this study. Questionnaires were handed out to the students under the supervision of investigators. Students were informed to complete the questionnaire according to one's own knowledge and not to consult each other and refer the literature while completing the questionnaire. Voluntary participation was sought and the students who declined to participate in the study were excluded.

\subsection{Data Analysis}

Upon completion of data gathering, data were coded and captured on Excel. The data was analyzed using SPSS version 16. In the statistical analysis, frequencies, mean values and percentages were presented. In comparison of study groups a chi-square $\mathrm{p}$ value $<0.05$ was considered statistically significant. A score was given to each factor which has been tested by the questioner and finally overall score was calculated. The scale related to the knowledge on laboratory safety knowledge was given as follow; the students who had scored $\geq 75$, 74$60,50-59$ and $\leq 49$ were categorized as "excellent", "good", "moderate" and "poor", respectively.

\section{RESULTS \& DISCUSSION}

Out of 229 participants the majority was B.Sc. in MLS undergraduates indicating the percentage of $45.4(n=104)$. In B. Pharmacy degree program there was $36.7 \% \quad(n=84)$ participants whereas from the B.Sc. (Nursing) degree program there was only $17.9 \%(n=41)$ participants. Table 1 shows the composition of the participants by the degree program and academic year to which they belong to.

Table 1. Composition of the study population by degree program and academic year

\begin{tabular}{|c|c|c|c|c|c|}
\hline \multirow[t]{2}{*}{ Degree program } & \multicolumn{4}{|c|}{ Academic year } & \multirow[t]{2}{*}{ Total } \\
\hline & $\begin{array}{l}\text { First } \\
\text { year }\end{array}$ & $\begin{array}{l}\text { Second } \\
\text { year }\end{array}$ & $\begin{array}{l}\text { Third } \\
\text { year }\end{array}$ & $\begin{array}{l}\text { Fourth } \\
\text { year }\end{array}$ & \\
\hline $\begin{array}{l}\text { B. Pharmacy: } \\
\text { Frequency } \\
\text { Percentage } \\
\text { within the } \\
\text { degree program }\end{array}$ & $\begin{array}{l}15 \\
17.9 \%\end{array}$ & $\begin{array}{l}23 \\
27.4 \%\end{array}$ & $\begin{array}{l}23 \\
27.4 \%\end{array}$ & $\begin{array}{l}23 \\
27.4 \%\end{array}$ & 84 \\
\hline $\begin{array}{l}\text { B.Sc. (MLS): } \\
\text { Frequency } \\
\text { Percentage } \\
\text { within the } \\
\text { degree program }\end{array}$ & $\begin{array}{l}16 \\
15.4 \%\end{array}$ & $\begin{array}{l}35 \\
33.7 \%\end{array}$ & $\begin{array}{l}26 \\
25 \%\end{array}$ & $\begin{array}{l}27 \\
26 \%\end{array}$ & 104 \\
\hline $\begin{array}{l}\text { B.Sc. (Nursing): } \\
\text { Frequency } \\
\text { Percentage } \\
\text { within the } \\
\text { degree program }\end{array}$ & $\begin{array}{l}31 \\
13.5 \%\end{array}$ & $\begin{array}{l}6 \\
14.6 \%\end{array}$ & $\begin{array}{l}14 \\
34.1 \%\end{array}$ & $\begin{array}{l}21 \\
51.2 \%\end{array}$ & 229 \\
\hline $\begin{array}{l}\text { Total: } \\
\text { Frequency } \\
\text { Percentage } \\
\text { within the } \\
\text { degree program }\end{array}$ & & & & & \\
\hline
\end{tabular}

Eleven different aspects of laboratory safety precautions given in the questionnaire were analyzed individually and the following observations were made; the students had a "good" knowledge in relation to safety laboratory practices, personal protective equipment, traceability and waste disposal. Furthermore the knowledge regarding gas, chemicals \& clinical specimens storage and glassware hazards was "moderate". But knowledge was "poor" regard to location \& operation of safety equipment, emergency 
procedures, health awareness, laboratory equipment and instruments (see Table 2). The mean value for overall knowledge on laboratory safety precautions was $51.4 \pm 18.1$. This is clearly indicated that an overall knowledge of "moderate" level with regard to laboratory safety precautions.

Table 2. Students' knowledge towards laboratory safety precautions

\begin{tabular}{|l|l|}
\hline Knowledge category & $\begin{array}{l}\text { Overall score } \\
(\text { Mean } \pm \text { SD) } \mathbf{n = 2 2 9}\end{array}$ \\
\hline Safety laboratory practices & $73.0 \pm 19.4$ \\
Personal protective equipment & $60.9 \pm 25.3$ \\
Traceability & $61.1 \pm 38.6$ \\
Waste disposal & $60.3 \pm 31.0$ \\
Gas & $57.2 \pm 34.2$ \\
Storage of chemicals \& clinical & $50.8 \pm 36.2$ \\
specimens & \\
Glassware hazards & $58.4 \pm 34.9$ \\
Location \& operation of safety & $22.8 \pm 15.4$ \\
equipment & \\
Emergency procedures & $33.1 \pm 22.9$ \\
Health awareness & $30.0 \pm 23.8$ \\
Laboratory equipment and instruments & $47.4 \pm 32.0$ \\
\hline
\end{tabular}

Furthermore, a detailed analysis of data specified that, only $7.4 \% \quad(n=17)$ of study population had an "excellent" knowledge towards the laboratory safety precautions. The number of undergraduates belong to knowledge level "good" and "moderate" were 63 (27.5\%) and $52(22.7 \%)$, respectively. Nevertheless the majority had been showed a "poor" knowledge including 97 of participants (42.4\%) (see Figure 1).

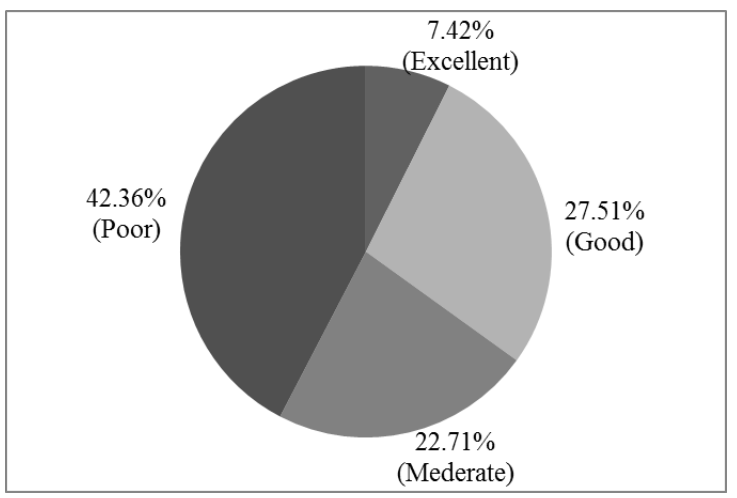

Figure1. Students overall knowledge towards laboratory safety precautions
It is very important to note that significant differences related to knowledge on laboratory safety precautions was observed among the degree programs. Out of three different degree programs B.Sc. in MLS undergraduates had a significantly higher knowledge $(p<0.05)$ compared to other two degree programs.

They showed "excellent" of 15.4\% $(n=16)$, "good" of $49 \%(n=51)$, "moderate" of $18.3 \%$ $(\mathrm{n}=19)$ and "poor" of $17.3 \%(\mathrm{n}=18)$. In B. Pharmacy degree program "excellent", "good", "moderate" and "poor' as follows; $1.2 \%(\mathrm{n}=1)$, $10.7 \%(n=9), 23.8 \%(n=20)$ and $64.3 \%(n=54)$, respectively whereas in B.Sc. (Nursing) degree program; good $7.3 \%(\mathrm{n}=3)$, moderate $31.7 \%$ $(\mathrm{n}=13)$ and poor were $61 \% \quad(\mathrm{n}=25)$, respectively (see Table 3 and Figure 2).

Table 3. Differences of laboratory safety knowledge among three degree programs

\begin{tabular}{|c|c|c|c|c|c|}
\hline \multirow[b]{2}{*}{$\begin{array}{l}\text { Degree } \\
\text { program }\end{array}$} & \multicolumn{4}{|c|}{ Knowledge } & \multirow{2}{*}{$\overrightarrow{0}$} \\
\hline & 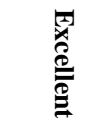 & $\begin{array}{l}\Omega \\
\stackrel{0}{0}\end{array}$ & 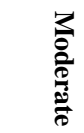 & 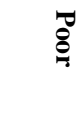 & \\
\hline $\begin{array}{l}\text { B. Pharmacy: } \\
\text { Frequency } \\
\text { Percentage } \\
\text { within the } \\
\text { degree } \\
\text { program }\end{array}$ & $\begin{array}{l}01 \\
1.2 \%\end{array}$ & $\begin{array}{l}09 \\
10.7 \%\end{array}$ & $\begin{array}{l}20 \\
23.8 \%\end{array}$ & $\begin{array}{l}54 \\
64.3 \%\end{array}$ & 84 \\
\hline $\begin{array}{l}\text { B.Sc. in MLS: } \\
\text { Frequency } \\
\text { Percentage } \\
\text { within the } \\
\text { degree } \\
\text { program }\end{array}$ & $\begin{array}{l}16 \\
15.4 \%\end{array}$ & $\begin{array}{l}51 \\
49 \%\end{array}$ & $\begin{array}{l}19 \\
18.3 \%\end{array}$ & $\begin{array}{l}18 \\
17.3 \%\end{array}$ & 104 \\
\hline $\begin{array}{l}\text { B.Sc. } \\
\text { (Nursing): } \\
\text { Frequency } \\
\text { Percentage } \\
\text { within the } \\
\text { degree } \\
\text { program }\end{array}$ & $\begin{array}{l}0 \\
0 \%\end{array}$ & $\begin{array}{l}3 \\
7.3 \%\end{array}$ & $\begin{array}{l}13 \\
31.7 \%\end{array}$ & $\begin{array}{l}25 \\
61 \%\end{array}$ & 41 \\
\hline $\begin{array}{l}\text { Total: } \\
\text { Frequency } \\
\text { Percentage } \\
\text { within the } \\
\text { degree } \\
\text { program }\end{array}$ & $\begin{array}{l}17 \\
7.4 \%\end{array}$ & $\begin{array}{l}63 \\
27.5 \%\end{array}$ & $\begin{array}{l}52 \\
22.7 \%\end{array}$ & $\begin{array}{l}97 \\
42.4 \%\end{array}$ & 229 \\
\hline
\end{tabular}




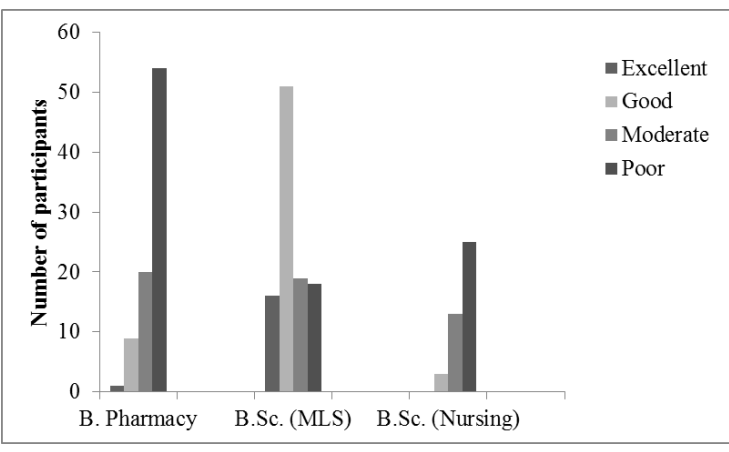

Figure 2. Differences of laboratory safety knowledge among three degree programs

However there was no significant difference observed among the students belong to different academic years within the same degree program.

The present study yielded very important findings pertaining to laboratory safety precautions among Allied Health Sciences students. The results clearly indicate that the insufficiency of knowledge regard to laboratory safety precautions in the study population as the students had gained the overall score of $51.4 \pm 15.1$ (Mean \pm SD) showing the lower marginal level of knowledge category "moderate". Hence these findings call for a lot of disquiets as laboratory safety precautions are extremely important for the study population, not only during their university life but also in their professions in the health care sector in the future too.

However we observed that the students are knowledgeable about safety laboratory practices such as washing hands before leaving the lab, not to practice mouth pipetting, decontamination of laboratory bench tops before leaving the laboratory, following of hazard warning labels and symbols appearing on the chemical containers, alert on turn off of gas, water, electricity, vacuum and compression lines and heating apparatus, not to consume foods and beverages inside the laboratory and not to allow unauthorized people to access the laboratory. They had obtained the highest score $(73 \pm 15.4)$ for safety laboratory practices out of all the eleven aspects tested by the questionnaire which comes under the upper marginal level of knowledge category "good". Though their knowledge was "good" towards personal protective equipment $(60.9 \pm 25.3)$, traceability $(61.1 \pm 38.6)$ and waste disposal $(60.3 \pm 31.0)$ the scores obtained were at the lower border line of knowledge category "good". Anyway the students had obtained a very low level of score for location \& operation of laboratory safety equipment $(22.8 \pm 15.4)$ though eye washers, safety showers, fire extinguisher are available in the laboratories of the university, emergency procedures (33.1 \pm 22.0$)$ and laboratory instruments \& equipment (47.4 \pm 32.0$)$. Another imperative factor we observed that health awareness was very poor among the study group which is indicated by the score of $30 \pm 23$. The different factors we tested under the health awareness were whether annual tuberculosis screening was done, vaccination against Hepatitis B and awareness regarding permissible exposure limit of hazardous chemicals. Possible reason may be, unawareness regarding the severity of the diseases such as tuberculosis, Hepatitis B etc. and the students should be educated concerning these facts.

Several studies have been indicated that through continuing education, training and retraining programs have a real potential on improving safety precautions among the target populations (Goswami et al., 2011; Islam et al., 2002; Odeyemi, 2012). A study carried out in Sri Lanka on sharp injuries among medical students in the faculty of Medicine, Colombo, Sri Lanka suggested that their curriculum should put more highlighting on improving the knowledge and practice on the topic of sharps injuries as out of 168 medical students, one or more sharp injury was experienced by $95 \%$ of the students. The study showed that $24 \%$ of students thought protection was not needed. The majority (97\%) of the study population believed that education regarding sharps 
injuries is important (Liyanage et al., 2012). The importance of education was evidenced by the present study too. Only the B.Sc. in MLS undergraduates had been lecturing regarding "Introduction to laboratory safety" during their very early stage in the university life prior to commencement the laboratory based learning in the university (personal communication). This may be a possible reason why B. Sc. in MLS undergraduates have shown a significantly higher knowledge $(\mathrm{p}<0.05)$ compared to B.Sc. (Nursing) and B. Pharmacy undergraduates. Hence potentially effective laboratory safety programs and workshops are extremely important to the students of the Allied Health Sciences degree program. Also, the students should have an enduring overt commitment to the safety programs and thus, compliance to the laboratory safety procedures should be made mandatory.

Furthermore it has been reported that the occurrence of infection with $\mathrm{HBV}$ has seen lowered effectively among health care workers mainly due to the immunization with hepatitis B vaccine in recent years (Poole et al., 1994). Therefore vaccination of undergraduates against hepatitis B should also be done while awareness on post prophylaxis should be extensively disseminated. This is important because it has been documented that health care workers are usually not aware on what type of prophylaxis measures to be taken in the occasion of exposure to blood and body fluids (Odusanya, 2003) and this might be valid to the study population of the present study too.

\section{CONCLUSION}

In overall, knowledge on laboratory safety precautions among Allied Health Sciences students is poor. But in comparison B.Sc. in MLS undergraduates had a significantly higher knowledge $(p<0.05)$ compared to other two degree programs. However, there was no significant difference regarding laboratory safety precautions among the students belong to different academic years within the same degree program.

\section{ACKNOWLEDGEMENT}

We are sincerely grateful to all the participants in this study for sparing their time to fill the questionnaires. We are also thankful to Mr. Inesh Prabuddha, Department of Statistics, Faculty of Allied Health Sciences, University of Sri Jayewardenepura for the assistance given during the statistical analysis.

\section{REFERENCES}

ADEBAMOWO CA \& AJUWON A. The immunization status and level of knowledge about Hepatitis B virus infection among Nigerian surgeons. West Afr J Med.1997; 16:93-6.

BRUSAFERRO S, MARTINA P \& PUZZOLANTE L. Epidemiological study on knowledge, attitudes and behavior of health care workers with respect to HIV infection. Med Lav. 1997; 88: 495-506.

FALOPE IA, ADEDEJI OO \& EYESAN SU. Incidence of HIV positivity in trauma victims over the age of 20 years. The Niger postgraduate Med J.1998; 5: 115-7.

GOSWAMI HM, SONI ST, PATEL SM \& PATEL MK. A study on knowledge, attitude and practice of laboratory safety measures among Paramedical staff of laboratory services. National Journal of Community Medicine. 2011; 2 (3): 470-3.

ISLAM MT, MOSTAFA G, BHUIYA AU, HAWKES $S$ \& DE FRANCISCO A. Knowledge on, and attitude toward, HIV/AIDS among staff of an international organization in Bangladesh. J Health Popul Nutr. 2002; 20(3): 271-8. 
KARIM N \& CHOE CK. Laboratory accidents - a matter of attitude. Malays J Pathol. 2000; 22(2):85-9.

LIYANAGE IK, CALDERA TSKRD, RAJAPAKSHA RWMA, LIYANAGE CK \& DE SILVA P. Sharps injuries among medical students in the faculty of Medicine, Colombo, Sri Lanka. Int J Occup Med Environ Health. 2012; 25(3):275-280.

MIAN MAH, MULLINS RF, ALAM B, BRANDIGI C, FRIEDMAN BC, SHAVER JR \& HASSAN Z. Workplace related burns. Ann Burns Fire Disasters. 2011; 30; 24(2): 89-93.

NWABUISI C \& OLATUNJI PO. Prevalence of Hepatitis B surface antigen amongst tertiary health workers in Ilorin. Nig Qrt J Hosp Med.1999; 9: 95-7.

ODEYEMI OA. Knowledge, awareness and compliance of postgraduate students to laboratory safety procedures. Bioresearch Bulletin 2012; 4: 180-4.

ODUSANYA OO. Awareness and compliance with Universal work precautions amongst health workers at an emergency medical service in Lagos, Nigeria. Niger Med J. 2003; 44:1.

POOLE CJM, MILLER S \& FILLINGHAM G. Immunity to hepatitis $B$ among health care workers performing exposure procedures. BMJ. 1994; 309: 94-5.

Prospectus, Allied Health Sciences Degrees, Faculty of Medical Sciences, University of Sri Jayewardenepura, 2012.

ZAVERI J \& KARIA J. Knowledge, attitudes and practice of laboratory technicians regarding universal work precaution. Natl J Med Res. 2012; 2(1):113-5. 